\title{
Exploring gender harassment among university teachers and researchers
}

\author{
Tuija Muhonen \\ Centre for Work Life and Evaluation Studies \\ Malmö University \\ Sweden
}

\section{Citation:}

Muhonen, T. (2016). Exploring gender harassment among university teachers and researchers. Journal of Applied Research in Higher Education, 8(1), 131-142.

\begin{abstract}
Purpose - The study examined the prevalence of gender harassment and how it was related to different organisational factors, ill-health and job satisfaction among women and men working as university teachers and researchers.
\end{abstract}

Methodology - A Web questionnaire was conducted in a university college in South Sweden. The final sample consisted of 322 participants, 186 women and 136 men.

Findings - The results showed that gender harassment was more prevalent among women than men, and among senior lecturers and professors than lecturers. Gender harassment was associated with high job demands, less fair leadership style of the immediate manager, and job dissatisfaction for both women and men. For women, there was also an association between gender harassment, ill-health and gender of the immediate manager. For men, poorer social organisational climate was related to gender harassment, but contrary to women, gender harassment was not related to the gender of the immediate manager.

Research limitations/implications - Even though the research was conducted only in one university, the results imply that gender harassment can have negative consequences for teachers and researchers. As the immediate manager's leadership style seems to be associated with the occurrence of gender harassment, universities should take this into consideration in their leadership programs.

Originality/Value - The paper highlights gender harassment, a subtle form of sexual harassment, among university teachers and researchers.

Keywords Gender harassment, University teachers, Leadership, Organisational factors, Job satisfaction, Ill-Health

Paper type Research paper

\section{Introduction}

The Swedish universities, like universities in other Western countries, are characterized by gender imbalance for example when it comes to the different scientific disciplines and the number of researchers (European Comission 2013; Husu 2005). While there is an overrepresentation of women in scientific disciplines such as health sciences, social care and teacher education, there is an under-representation of women in disciplines such engineering and science (European Comission 2013; Husu 2005). Universities have historically been male dominated milieus and even though the number of women both among students and teachers has increased, the vast majority of researchers and especially professors are men. There are indications that women who work in a male dominated environment encounter sexual harassment (Berdahl 2007b; Bildt 2005). In order to emphasize the sexist rather than sexual motives that trigger this kind of behavior researchers make a distinction between sexual harassment and sex-based harassment (Berdahl 2007a). Sex-based harassment or gender 
harassment is considered the most common form of sexual harassment Berdahl (2007a), and has been defined as verbal and nonverbal behaviours that convey insulting, hostile and degrading attitudes towards women (Fitzgerald et al., 1995). Exposure to sexual harassment has also been found to be related to poorer health, well-being and work-related aspects, like job-dissatisfaction (Fitzgerald et al., 1997; McDonald 2012).

Husu (2001) found in her study that behind the alleged gender equality in the universities different subtle discriminating actions could be discerned. This finding indicates that the gender harassing behaviour in academia is more subtle rather than vulgar and obvious. Earlier research concerning sexual harassment in academia has mostly focused on students and not the staff e.g. (Bildt 2005). The aim of the current study was to examine the prevalence of gender harassment and how it was related to different organisational factors, illhealth and job satisfaction among women and men working as university teachers and researchers.

\section{Literature review}

\section{Higher education as a workplace}

Higher education in Sweden is a rather large state employer consisting of 75,700 individuals and 57 per cent of this total number are employees with research or teaching duties (Swedish Higher Education Authority 2014). The research and teaching staff comprises mainly of senior lecturers (28\%) and professors (18\%) and lecturers (18\%). Women represent $56 \%$ of the lecturers, $45 \%$ of the senior lecturers, whereas the share of women professors is only 24 per cent in Sweden (Statistics Sweden 2014).

Historically, academia has been considered, and still is regarded, as a privileged workplace since it is associated with freedom, autonomy, inspiration and good career possibilities (Källhammer 2008). At the same time different political reforms such as the Bologna process and the ever-increasing new public management ideology in the form of marketisation have brought about fundamental changes in the higher education sector (Ek et al., 2013). These changes have resulted in high workload for the teaching staff. They experience lack of time and support, concurrently viewing their work tasks as fragmented and combined with constant audits. Taken together these conditions can lead to stress and ill health for the teaching staff (Källhammer 2008). Several studies point out that these kind of negative factors in the working environment can give rise to harassing behaviours at the workplace (Bowling and Beehr 2006; Salin et al., 2011).

\section{Gender harassment in organisations}

Workplace sexual harassment was acknowledged as a phenomenon in the 1970s and several studies in the field have been conducted since then (McDonald 2012). The concept of sexual harassment can lead to false associations about the motives being sexual desire or sexual relations, but studies show that this kind of harassment mainly aims to derogate and dominate the victim based on gender rather than to have sexual relation with the victim (Berdahl 2007a). Some researchers make a distinction between sexual harassment and sex-based harassment in order to emphasize the sexist rather than sexual motives that lie behind the behaviour (Berdahl 2007a). Gender harassment has been defined as verbal and nonverbal behaviours that convey insulting, hostile and degrading attitudes towards women (Fitzgerald et al.; 1995). According to Berdahl (2007a) gender harassment is the most common form of sexual harassment, consisting of e.g. sexist comments and jokes.

Compared with sexual harassment there is little research about gender harassment in organisations (Leskinen et al., 2011). Since gender harassment does not include overt unwanted sexual attention it is considered as a milder and less serious form of harassment and has therefore not received the same attention as sexual harassment by researchers nor by 
organisations (Leskinen et al., 2011). Exposure to sexual harassment has been found to be related to poorer health, well-being and work-related aspects, like job-dissatisfaction (Fitzgerald et al., 1995; McDonald 2012). Likewise, there is some evidence that women who have been exposed to gender harassment show negative professional and personal outcomes (Leskinen et al., 2011). When it comes to antecedents, the stressful work environment has been pointed out as a predictor workplace harassment (Bowling and Beehr 2006). According to earlier studies women more often report ill effects on health than men do (Torkelson and Muhonen 2008), and this seems to apply even among university personnel (Bildt 2005; Moen et al., 2013). Further, leadership in the organisation can influence the prevalence of harassing behaviour, e.g. if management appears to tolerate or ignore harassment, men are more inclined to harass women (Schneider et al., 2010).

\section{Gender equality and higher education}

The Swedish universities, like universities in other Western countries, are gender segregated concerning the scientific disciplines as well as the academic hierarchy (European Comission 2013; Husu 2005). Even though the number of women both among students and teachers has increased, researchers and especially professors are mainly men. Currently the proportion of male professors is 76 per cent in Sweden (Swedish Higher Education Authority 2014).

In a review of research on gender equality in the Swedish universities Dahlerup (2010) observes that this is a relatively new field, even though the number of studies has increased somewhat during the last ten years. Several studies point out that sexual harassment in the universities can be recognized as a general problem, but that it exists somewhere else, not in ones own organisation or among one's colleagues (Dahlerup 2010). Academia is considered as based on objective meritocratic principles and therefore gender is often regarded as a nonissue and irrelevant since it is competence and qualifications that matter and not gender (Van den Brink and Benschop 2012).

According to a Swedish legal definition, there is a gender balance or quantitative gender equality, in the organisation when the proportion of women or men does not exceed 60 per cent of the employees (Silander et al., 2013). If an organisation comprises more than 60 per cent women, it is considered as women-dominated, whereas it is men-dominated if more than 60 per cent of the employees are men. The term qualitative gender equality implies "that the knowledge, experiences and values of both women and men are given equal weight and are used to enrich and direct all spheres of society" (Statistics Sweden 2014).

There are indications that women who work in a male dominated environment encounter sexual harassment (McLaughlin et al., 2012), but earlier research concerning sexual harassment in academia has mostly been focused on students and not the staff e.g. (Bildt 2005). Husu (2005) found in her study that behind the purported gender equality in the universities different subtle discriminating actions could be discerned. This finding indicates that the gender harassing behaviour in academia is more indirect rather than direct or obvious.

\section{The current study}

This study is part of a larger project conducted in a university college in South Sweden that has quantitative gender equality, i.e. gender balance, among teachers, heads of department and almost among professors as well (Muhonen et al., 2012). The aim of the project was to examine whether the organisation was characterized by qualitative gender equality, i.e. equal working conditions for women and men both among the middle managers (heads of department) and their employees (teachers and researchers). Against this background, the aim of the current study therefore was to examine the prevalence of gender harassment and how it was related to different organisational factors, ill-health and job satisfaction among women and men working as university teachers. 
The following research questions are put forward:

1. How prevalent is gender harassment among the teaching staff in the organisation?

2. Do women and men in different teaching positions differ in perceived gender harassment?

3. How is gender harassment related to organisational factors, (i.e. job demands, control at work, social climate, immediate managers leadership style and gender of immediate manager), ill-health and job satisfaction?

\section{Method}

\section{Participants}

A Web questionnaire was conducted among all the university teachers who had a permanent or a temporary employment of at least 50 per cent $(n=553)$ in a university college in South Sweden in Spring 2010. An e-mail containing a link to the Web questionnaire was sent to the teachers and after two reminders 332 teachers had responded, giving a response rate of 60 per cent. Since the focus in this study was on lecturers, senior lecturers and professors 10 of the participants were excluded as they had another kind of teaching assignment (e.g. clinical tutoring). The final sample consisted therefore of 322 participants, 186 women and 136 men.

As can be seen in Table I around half of the participants were 51 years of age or older. The vast majority of women as well as men had a permanent position. 54 per cent of the women and 37 per cent of the men reported that their immediate manager was a woman. The men and women did not differ significantly concerning the background factors, except for position, men having position as senior lecturer or professor to a greater extent than women.

[Insert Table I around here]

A non-response analysis conducted by $t$-tests showed no differences in terms of gender, age, position or employment between the teaching staff that replied to the questionnaire, and those who did not. The group of participants can therefore be regarded as representative for the studied university.

\section{Measures}

The background questions included age ( $1=40$ years or younger, $2=41-50$ years, $3=51-60$, $4=$ over 60 years), gender (1=man, $2=$ =woman), position (1=lecturer, $2=$ senior lecturer/professor), employment (1=permanent, $2=$ temporary), and gender of the immediate manager (1=woman, $2=$ man). Concerning participants' position, lecturers are teachers who contrary to senior lecturers and professors do not have a PhD degree. Due to a relatively small number of professors, they were included in the same category with senior lecturers.

Gender harassment was assessed by four items inspired by Ås (1978). The participants were asked if they had during the past 12 months experienced gender harassment at their work place in the form of: (1) encountering sexist or gender harassing language, (2) being made invisible e.g. in meetings, (3) being ridiculed, (4) being discriminated concerning their salary. Respondents rated the four items on a scale ranging from 1 (very rarely/never) to 5 (very often).

The organisational factors including leadership style were measured with items from QPSNordic (Elo et al., 2000). Job demands were measured by two items, "Is your work irregular so that the work piles up? and "Do you have too much to do?" Control at work was assessed by one item: “Can you influence decisions that are important for your work?" Social organisational climate was measured by three items, a sample item being: "The climate at my department is encouraging and supportive”. Participants responded on a five- point scale from 1 (disagree totally) to 5 (agree totally). Leadership style was assessed by two scales. 
Empowering leadership was measured by three items, e.g. "My immediate manager encourages me to speak up when I have different opinions.” Participants responded on a fivepoint scale from 1 (disagree totally) to 5 (agree totally). Fair leadership was assessed by two items, e.g. "My immediate manager distributes the work fairly and impartially". Participants responded on a five-point scale from 1 (disagree totally) to 5 (agree totally)

Ill-health was assessed by 7 items from Hopkins Symptom Checklist-25 (HSCL-25) (Derogatis et al., 1974) measuring symptoms such as headache, insomnia and anxiety. Respondents rated the intensity of different symptoms on a scale ranging from 1 (= not bothered) to 4 (= extremely bothered).

Job satisfaction was measured by three items from Copenhagen Psychosocial Questionnaire (Kristensen and Borg 2003). One example item: "How pleased are you with your work prospects?” Participants responded on a four-point scale from 1 (=very satisfied) to 4 (=highly unsatisfied).

Means, standard deviations and Cronbach alpha reliabilities can be found in Table III.

\section{Data analysis}

The data was analysed in SPSS, initially by descriptive statistics. In order to examine differences related to gender and position and potential interaction effects Multivariate analysis of variance (MANOVA) was conducted. The associations between gender harassment, different organisational factors, ill-health and job satisfaction were analysed by separate Spearman correlations for women and men.

\section{Results}

Prevalence of gender harassment higher for women

The descriptive analysis showed that 64 per cent of the men and 34 per cent of the women had very seldom or never perceived gender harassment. This result means that a vast majority of women (66\%) had experienced gender harassment at the workplace to some extent (from very seldom to very often) during the last year.

\section{Greater exposure to gender harassment in women and senior faculty}

In order to examine the differences between women and men concerning gender harassment, organisational factors, ill-health and job satisfaction, MANOvAs were conducted. The position was also included in the analysis, since it is often postulated that one's position in the organisation is more important than gender, and lecturers are considered to be worse off in different ways in the university hierarchy. Therefore, it was relevant to analyse if there were any differences related to position when it comes to gender equality and harassment. The results of MANOvAs presented in Table II show that women and men differ significantly concerning exposure to gender harassment, women experiencing harassment to a greater extent than men. Further, the results showed a significant difference related to position and gender harassment, indicating that the senior lecturers/professors were more exposed to gender harassing behaviour than were the lecturers. No significant differences related to either gender or position were found concerning job demands, control at work, social climate, empowering leadership, fair leadership, ill-health or job satisfaction. There were no significant interaction effects between gender and position concerning the studied variables.

[Insert Table II around here]

Gender harassment for women is associated with job demands, job dissatisfaction, ill-health, male managers and less fair leadership

Separate Spearman correlations for women and men were conducted in order to find out how 
gender harassment was related to job demands, control at work, social climate, gender of immediate manager, immediate managers leadership style (empowering and fair leadership), ill-health and job satisfaction. The results of the correlation analyses can be seen in Table III. The results for women showed that gender harassment had a significant positive correlation with job demands, indicating that those participants who experienced gender harassment also perceived that they had high job demands. Gender harassment was negatively related to fair leadership style of the immediate manager. Furthermore, gender harassment was significantly associated with both ill-health and job dissatisfaction. Gender harassment was also related to the gender of the immediate manager, indicating less harassment when the immediate manager was a woman.

\section{[Insert Table III around here]}

Gender harassment for men is associated with job demands, job dissatisfaction, less fair leadership and less empowering leadership

When it comes to men the analyses showed that gender harassment was associated with high job demands, poorer social organisational climate and less fair leadership style of the immediate manager and job dissatisfaction. There was also a significant relationship between gender harassment and less empowering leadership style of the immediate manager. Contrary to women, gender harassment was not related to the gender of the immediate manager.

\section{Discussion}

The current study was conducted in a university college that is characterized by quantitative gender equality or gender balance. It was therefore interesting to examine if this would be portrayed even in more qualitative terms, such as absence of gender harassment. The aim of the study was to investigate the prevalence of gender harassment among university teachers and researchers. A further aim was to explore, how it was related to different organisational factors such as job demands, control at work, social climate, leadership style and gender of the immediate manager, but also to ill-health and job satisfaction.

Despite the quantitative gender equality in the organisation, the results showed that a majority of women had experienced gender harassment to some extent (from very seldom to very often) during the last year at their workplace. There was also a significant gender difference in line with earlier studies showing that women are more exposed to sex harassment than men (Bildt 2005; McLaughlin et al., 2012). When it comes to position, it appeared that the senior lecturers and professors were more exposed to gender harassment than lecturers. This was an unexpected finding, since the lecturers, predominantly women, are generally considered a disadvantaged group in the universities.

Earlier studies among university personnel have shown that women report poor health more often than men do (Bildt 2005; Moen et al., 2013). This pattern was not found in the current study. There were no significant gender differences related to either ill-health or job satisfaction. Further, women and men did not differ concerning the perceived job demands, control at work, social climate, and the immediate managers leadership style (empowering leadership and fair leadership). Likewise there were no significant differences related to position concerning the organisational factors, ill-health or job satisfaction. No significant interaction effects were found between gender and position concerning the studied variables. It therefore appears that women and men, irrespective of their organisational position, perceived the working environment in the organisation in a similar way.

In order to find out how gender harassment was related to job demands, control at work, gender of immediate manager, immediate managers leadership style (empowering and fair leadership), ill-health and job satisfaction separate correlations were conducted for women 
and men. The results showed both similarities and some differences for women and men. Gender harassment was associated with high job demands and less fair leadership style of the immediate manager both among women and men. These results are in line with earlier research pointing out stressful work environment as a predictor for workplace harassment (Bowling and Beehr 2006), but also indicating the importance of leadership style for the occurrence of harassing behaviours (Schneider et al., 2010). Further, an association between gender harassment and job dissatisfaction was found for both women and men, whereas gender harassment was even related to ill-health among women and poorer social organisational climate among men. Earlier studies have shown that sexual harassment is related to poorer health, well-being and job dissatisfaction (Fitzgerald et al., 1995; McDonald 2012), but the current study suggests that even gender harassment has similar negative associations.

Further, women whose immediate manager was a woman experienced significantly less gender harassment, whereas this was not the case for men. This is an interesting finding as it indicates that the manager's gender might make a difference concerning harassing behaviour at the workplace. On the other hand, it could be due to the fact that women are managers for a group of employees consisting mainly of women, and that the gender composition of the group might play a significant role. As the data does not include information concerning which department or unit the employees belong to, further analyses testing the gender composition at the organisational level could not be conducted. This is therefore an issue for future research to investigate.

Several studies point out that factors in the work organisation play an important role when it comes to occurrence of harassing behaviour (Bildt 2005; Bowling and Beehr 2006). This indicates that gender harassment should be regarded as an organisational rather than an individual problem. Therefore, organisational measures need to be focused upon to prevent gender harassment. Leskinen et al., (2011, p. 28) point out that "Gender harassment may be used to cue women that they are inadequate, out of place, and unable to perform at the level of men" (Leskinen et al., 2011). It can therefore be postulated that besides consequences for women's health and job satisfaction gender harassment has negative effects for women's career development.

Limitations of the current study include the cross-sectional design that prohibits causal claims about the directions of the relationships discovered. The usage of self-report measures can lead to inflated correlations attributed to common method variance (Beehr et al., 2001). The scale for measuring gender harassment in this study was inspired by Ås (1978). Even though it had reasonably high alpha value, the scale needs to be developed further, e.g. including more items to identify different harassing behaviours. In addition, the study was conducted in one organisation, which limits the generalizability of the findings.

As gender harassment in universities has mainly been studied among students (Bildt 2005), there is need for further studies focusing on researchers and teachers in order to find out what kind of harassing behaviours exist in academia. Universities have traditionally been regarded as based upon gender-neutral meritocratic principles (Dahlerup 2010), but subtle harassing expressions can be hidden under the surface (Husu 2000; Husu 2005). The current study gives rise to future research questions that need to be addressed such as the impact of gender of the immediate manager on gender harassment in the universities. There is also need for more intersectional studies, that besides gender, include factors like ethnicity and age as instigators of harassing behaviour (Dahlerup 2010). . As the immediate managers leadership style seems to be associated with occurrence of gender harassment, universities should take this finding into consideration in their leadership programs. 


\section{Acknowledgements}

To conclude, the prevalence of gender harassment in the studied organisation, especially among women, suggests that establishing quantitative gender equality does not guarantee qualitative gender equality in the organisation. The results indicate that gender harassment, considered as a milder form of sexual harassment, was related to both ill-health, dissatisfaction at work and to the leadership style of the immediate manager This study was financed by DJ, Delegationen för jämställdhet i högskolan [Delegation for gender equality in higher education (U 2009:01)], Sweden.

\section{References}

Beehr, T. A., Glaser, K. M., Canali, K. G., and Wallwey, D. A. (2001). "Back to basics: Reexamination of demand-control theory of occupational stress." Work \& Stress, 15(2), 115-130.

Berdahl, J. L. (2007a). "Harassment based on sex: Protecting social status in the context of gender hierarchy." Academy of Management Review, 32(2), 641-658.

Berdahl, J. L. (2007b). "The sexual harassment of uppity women." Journal of Applied Psychology, 92(2), 425.

Bildt, C. (2005). "Sexual harassment: Relation to other forms of discrimination and to health among women and men." Work: A Journal of Prevention, Assessment and Rehabilitation, 24(3), 251-259.

Bowling, N. A., and Beehr, T. A. (2006). "Workplace harassment from the victim's perspective: a theoretical model and meta-analysis." Journal of Applied Psychology, 91(5), 998.

Dahlerup, D. (2010). Jämställdhet i akademin: en forskningsöversikt, Stockholm: Delegationen för jämställdhet i högskolan (DJ).

Derogatis, L. R., Lipman, R. S., Rickels, K., Uhlenhuth, E. H., \& Covi, L. (1974). The Hopkins Symptom Checklist (HSCL): A self-report symptom inventory. Behavioral science, 19(1), 1-15.

Ek, A.-C., Ideland, M., Jönsson, S., and Malmberg, C. (2013). "The tension between marketisation and academisation in higher education." Studies in Higher education, 38(9), 1305-1318.

Elo, A.-L., Skogstad, A., Dallner, M., Gamberale, F., Hottinen, V., and Knardahl, S. (2000). User's guide for the QPSNordic: General Nordic Questionnaire for psychological and social factors at work: Nordic Council of Ministers.

European Comission. (2013). She figures 2012. Gender in research and innovation.

Fitzgerald, L. F., Drasgow, F., Hulin, C. L., Gelfand, M. J., and Magley, V. J. (1997). "Antecedents and consequences of sexual harassment in organizations: a test of an integrated model." Journal of Applied Psychology, 82(4), 578.

Fitzgerald, L. F., Gelfand, M. J., and Drasgow, F. (1995). "Measuring sexual harassment: Theoretical and psychometric advances." Basic and Applied Social Psychology, 17(4), 425-445.

Husu, L. (2000). "Gender discrimination in the promised land of gender equality." Higher Education in Europe, 25(2), 221-228.

Husu, L. (2001). "Sexism, support and survival in academia." Academic Women and Hidden Discrimination in Finland. Helsinki: University of Helsinki, Department of Social Psychology.

Husu, L. (2005). Dold könsdiskriminering på akademiska arenor: osynligt, synligt, subtilt: Högskoleverket. 
Kristensen, T., and Borg, V. (2003). "Copenhagen Psychosocial Questionnaire (COPSOQ) A questionnaire on psychosocial working conditions, health and well-being in three versions." Unpublished manuscript, National Institute of Occupational Health, Denmark.

Källhammer, E. (2008). "Akademin som arbetsplats: hälsa, ohälsa och karriärmöjligheter ur ett genusperspektiv."

Leskinen, E. A., Cortina, L. M., and Kabat, D. B. (2011). "Gender harassment: broadening our understanding of sex-based harassment at work." Law and Human Behavior, 35(1), 25.

McDonald, P. (2012). "Workplace sexual harassment 30 years on: a review of the literature." International Journal of Management Reviews, 14(1), 1-17.

McLaughlin, H., Uggen, C., and Blackstone, A. (2012). "Sexual harassment, workplace authority, and the paradox of power." American Sociological Review 77(4),

625-647.

Moen, B. E., Wieslander, G., Bakke, J. V., and Norbäck, D. (2013). "Subjective health complaints and psychosocial work environment among university personnel." Occupational Medicine, 63(1), 38-44.

Muhonen, T., Liljeroth, C., and Lindqvist Scholten, C. (2012). Vad innebär jämn könsfördelning på mellanchefsnivå för den kvalitativa jämställdheten $i$ organisationen?, Malmö högskola, Malmö.

Salin, D., Hoel, H., Einarsen, S., Hoel, H., Zapf, D., and Cooper, C. (2011). "Organisational causes of workplace bullying." Bullying and harassment in the workplace: Developments in theory, research, and practice, 227-243.

Schneider, K., Pryor, J., and Fitzgerald, L. (2010). "Sexual harassment research in the United States." Bullying and harassment in the workplace: Developments in theory research and practice, 245-266.

Silander, C., Haake, U., and Lindberg, L. (2013). "The different worlds of academia: a horizontal analysis of gender equality in Swedish higher education." Higher Education, 66(2), 173-188.

Statistics Sweden. (2014). Women and men in Sweden: facts and figures 2014.

Swedish Higher Education Authority. (2014). Higher education in Sweden - 2014 status report. Universitetskanslersämbetet, Stockholm.

Torkelson, E., and Muhonen, T. (2008). "Work stress, coping, and gender: implications for health and well-being", in K. Näswall, J. Hellgren, and M. Sverke, (eds.), The individual in the changing working life. Cambridge: Cambridge University Press, pp. 311-327.

Van den Brink, M., and Benschop, Y. (2012). "Gender practices in the construction of academic excellence: Sheep with five legs." Organization, 19(4), 507-524.

Ås, B. (1978). "Hersketeknikker." Master Suppression Techniques.] Kjerringråd, 3, 17-21. 
Table I. Descriptive data for the participants.

\begin{tabular}{|c|c|c|c|c|c|c|}
\hline \multirow[b]{2}{*}{ Variable } & \multicolumn{2}{|c|}{ Women $(n=186)$} & \multicolumn{2}{|c|}{ Men $(n=136)$} & \multirow[t]{2}{*}{$\underline{t}$} & \multirow[t]{2}{*}{$\underline{d f}$} \\
\hline & No. & $\%$ & No. & $\%$ & & \\
\hline Age & & & & & -.95 & 320 \\
\hline 50 years or younger & 83 & 45 & 68 & 50 & & \\
\hline 51 years or older & 103 & 55 & 68 & 50 & & \\
\hline Employment & & & & & -.13 & 315 \\
\hline Permanent & 170 & 93 & 125 & 92 & & \\
\hline Temporary & 13 & 7 & 9 & 8 & & \\
\hline Position & & & & & $2.82 * *$ & 320 \\
\hline Lecturer & 110 & 59 & 59 & 43 & & \\
\hline Senior lecturer or professor & 76 & 41 & 77 & 57 & & \\
\hline
\end{tabular}


Table II. F Ratios for differences on organizational factors related to gender and position

\begin{tabular}{|c|c|c|c|c|c|c|c|}
\hline \multirow[b]{2}{*}{ Variable } & \multirow[b]{2}{*}{$\begin{array}{l}\text { Women } \\
(n=186)\end{array}$} & \multirow[b]{2}{*}{$\begin{array}{r}\text { Men } \\
(n=136)\end{array}$} & \multirow[b]{2}{*}{$\begin{array}{r}\text { Lecturers } \\
(\mathrm{n}=169)\end{array}$} & \multirow[b]{2}{*}{$\begin{array}{r}\text { Senior } \\
\text { lecturers/ } \\
\text { Professors } \\
(\mathrm{n}=153)\end{array}$} & \multicolumn{3}{|c|}{$F$} \\
\hline & & & & & Gender & Position & $\mathrm{G} \times \mathrm{P}$ \\
\hline \multicolumn{8}{|l|}{ Job Demands } \\
\hline$M$ & 7.98 & 7.81 & 7.78 & 8.05 & & & \\
\hline$S D$ & 1.56 & 1.36 & 1.51 & 1.44 & 0.96 & 3.28 & 0.00 \\
\hline \multicolumn{8}{|l|}{ Influence } \\
\hline$M$ & 3.42 & 3.48 & 3.43 & 3.46 & & & \\
\hline$S D$ & 0.87 & 0.94 & 0.91 & 0.88 & 0.07 & 0.02 & 0.22 \\
\hline \multicolumn{8}{|c|}{ Social climate } \\
\hline$M$ & 10.87 & 11.30 & 11.18 & 10.93 & & & \\
\hline$S D$ & 2.47 & 2.53 & 2.25 & 2.75 & 3.02 & 2.06 & 0.06 \\
\hline \multicolumn{8}{|l|}{$\begin{array}{c}\text { Empowering } \\
\text { leadership }\end{array}$} \\
\hline$M$ & 11.27 & 12.01 & 11.60 & 11.58 & & & \\
\hline$S D$ & 4.20 & 4.23 & 4.03 & 4.44 & 1.21 & 0.05 & 0.01 \\
\hline \multicolumn{8}{|c|}{ Fair leadership } \\
\hline$M$ & 7.92 & 8.53 & 8.03 & 8.35 & & & \\
\hline$S D$ & 2.82 & 2.90 & 2.87 & 2.85 & 1.98 & 0.01 & 0.27 \\
\hline \multicolumn{8}{|c|}{ Gender harassment } \\
\hline$M$ & 6.61 & 5.08 & 5.56 & 6.41 & & & \\
\hline$S D$ & 2.98 & 2.16 & 2.47 & 3.01 & $26.24 * *$ & $9.21 * *$ & 0.12 \\
\hline \multicolumn{8}{|l|}{ Ill-health } \\
\hline$M$ & 13.28 & 13.12 & 13.14 & 13.29 & & & \\
\hline$S D$ & 4.46 & 4.09 & 4.11 & 4.51 & 0.14 & 0.04 & 0.00 \\
\hline \multicolumn{8}{|c|}{ Job satisfaction } \\
\hline$M$ & 8.01 & 7.90 & 7.93 & 7.99 & & & \\
\hline$S D$ & 1.75 & 1.79 & 1.76 & 1.78 & 0.09 & 0.01 & 0.75 \\
\hline
\end{tabular}

$* p<0.05 ; * * p<0.01$ 
Table III. Means, standard deviations, Cronbach’s alphas and Spearman correlations for the study variables ${ }^{\mathrm{a}, \mathrm{b}, \mathrm{c}}$

\begin{tabular}{|c|c|c|c|c|c|c|c|c|c|c|c|c|c|c|c|}
\hline & & Mean & $\mathrm{SD}$ & $\alpha$ & & & & & & $r_{s}$ & & & & & \\
\hline & & & & & 1. & 2. & 3. & 4. & 5. & 6. & 7. & 8. & 9. & 10. & 11. \\
\hline 1. & $\operatorname{Age}^{\mathrm{d}}$ & $2.52(2.46)$ & $1.00(1.01)$ & $\mathrm{NA}^{\mathrm{g}}$ & - & .08 & -.01 & -.06 & .14 & .10 & .01 & -.03 & .01 & -.08 & .11 \\
\hline 2. & Position $^{\mathrm{e}}$ & $1.41(1.57)$ & $0.49(0.50)$ & NA & .06 & - & .03 & .09 & .01 & -.05 & -.02 & .02 & .27 & .07 & .07 \\
\hline 3. & Gender of immediate manager ${ }^{\mathrm{f}}$ & $1.46(1.63)$ & $0.50(0.48)$ & NA & -.03 & .36 & - & -.01 & -.03 & -.08 & -.02 & -.08 & .08 & .10 & -.06 \\
\hline 4. & Job demands & 7.98 (7.81) & 1.56 (1.36) & .60 & .06 & .11 & .10 & - & -.28 & -.20 & -.12 & -.21 & .30 & .39 & -.33 \\
\hline 5. & Control at work & $3.42(3.48)$ & $0.87(0.94)$ & NA & -.14 & .01 & .07 & -.22 & - & .46 & .37 & .41 & -.13 & -.29 & .59 \\
\hline 6. & Social climate & $10.87(11.30)$ & $2.47(2.53)$ & .79 & -.13 & -.04 & .07 & -.22 & 50 & - & .54 & .58 & -.23 & -.17 & .55 \\
\hline 7. & Empowering leadership & $11.27(12.01)$ & $4.20(4.23)$ & .89 & -.22 & .01 & .00 & -.11 & .51 & .54 & - & .72 & -.10 & -.16 & .41 \\
\hline 8. & Fair leadership & 7.92 (8.53) & $2.82(2.90)$ & .90 & -.17 & .06 & .01 & -.10 & .38 & .54 & .73 & - & -.18 & -.16 & .47 \\
\hline 9. & Gender harassment & $6.61(5.08)$ & $2.98(2.16)$ & .78 & -.03 & .22 & .22 & .19 & -.05 & -.15 & -.12 & -.22 & - & .11 & -.22 \\
\hline 10. & Ill-health & $13.28(13.12)$ & 4.46 (4.09) & .84 & -.04 & -.06 & -.06 & .47 & -.27 & -.22 & -.19 & -.11 & .16 & - & -.41 \\
\hline 11. & Job satisfaction & $8.01(7.90)$ & 1.75 (1.79) & .62 & .09 & -.05 & -.01 & -.35 & .36 & .36 & .29 & .32 & -.28 & -.28 & 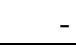 \\
\hline
\end{tabular}

Notes: ${ }^{a)}$ Means and standard deviations for women are given without parentheses and for the men with parentheses; ${ }^{b}$ ) the correlation matrix for the women is given below the diagonal and the correlation matrix for the men above the diagonal; 'Female participants, $\mathrm{n}=186-172$, Male participants, $\mathrm{n}=136-125$; ${ }^{\mathrm{d}}$ Age was coded as $1=\leq 40$ years, $2=41-50$ years, $3=51-60$ years, $4=\geq 60$; $\mathrm{e}$ positions was coded as $1=$ =lecturer, $2=$ senior lecturer or professor; ${ }^{\mathrm{f}}$ Gender of immediate manager was coded as $1=$ woman, $2=$ man. ${ }^{\mathrm{g}} \mathrm{NA}=$ not applicable. Bold style indicates that $p<0.05$. 
